\title{
Effect of Bio-phosphate and Chemical Phosphorus Fertilizer Accompanied with Foliar Application of Micronutrients on Yield, Quality and Phosphorus and Zinc Concentration of Maize
}

\author{
Mohammad Galavi, Khatoon Yosefi \& Mahmod Ramrodi \\ Department of agronomy, collage of agriculture \\ University of Zabol, P.O.Box 98615-538, Zabol, Iran \\ Tell: 98-542-222-5077Ｅ-mail:mgalavi@yahoo.com
}

Sayed Roholla Mousavi (Corresponding author)

Aligoudarz Branch, Islamic Azad University, Aligoudarz, Iran

Tell: 98-664-223-4731 E-mail: rr_mousavi@yahoo.com

Received: March 2, 2011

doi:10.5539/jas.v3n4p22
Accepted: March 23, 2011 Published: December 1, 2011

URL: http://dx.doi.org/10.5539/jas.v3n4p22

\begin{abstract}
Field experiment was conducted at Kerman Agricultural and Natural Resources Research Centre (Iran) during 2008-2009 to evaluate the effect of bio-fertilizer, phosphorus and foliar application of micronutrients on dry matter accumulation, yield, and phosphorus and zinc concentration of maize (Zea mays L.). A split plot experiment based on randomized complete blocks design (RCBD) with four replications was followed in the study. The micronutrients foliar application in two levels (foliar application and non foliar application) were the main plots, and four levels of phosphate $\left(\mathrm{T}_{1}: 0\right.$ (no fertilizer), $\mathrm{T}_{2}: 100 \mathrm{~kg} \mathrm{ha}^{-1} \mathrm{P}_{2} \mathrm{O}_{5}, \mathrm{~T}_{3}: 100 \mathrm{~g}$ bio-phosphate, $\mathrm{T}_{4}$ : $100 \mathrm{~g}$ bio-phosphate with $50 \mathrm{~kg} \mathrm{ha}^{-1} \mathrm{P}_{2} \mathrm{O}_{5}$ ) as the sub plots. Results showed that micronutrients foliar application and biological and chemical phosphorus fertilizers had a significant influence on dry matter accumulation. The maximum dry matter accumulation was obtained by applying $50 \mathrm{~kg} / \mathrm{ha} \mathrm{P}_{2} \mathrm{O}_{5}$ plus bio-fertilizer. Grain yield, 1000 -seed weight and protein content of grain were significantly affected by micronutrients and phosphorus fertilizers treatments. Micronutrients foliar application and phosphorus fertilizers interaction had no significantly effect on grain yield, 1000-seed weight and grain protein content. Grain phosphorus and zinc concentration where significantly increased by application of micronutrients and phosphorus fertilizers.
\end{abstract}

Keywords: Bio-phosphate, Dry matter, Maize, Micronutrient, Yield

\section{Introduction}

Integration of chemical and bio-fertilizers is one of the ways to increase production in sustainable agriculture (Ali et al. 2008; Sharma, 1999). Phosphorus bio-fertilizers bacteria such as Bacillus and Pseudomonas increased soil soluble phosphorus by secreting organic acids and phosphatase enzyme (Ehteshami et al. 2007). Environmental problems caused by irregular application of chemical fertilizers, inappropriate energy production methods and excessive consumption costs have all had harmful effects on biological cycles and destroyed farming stability systems; these factors altogether encourage the application of bio fertilizers (Kannayan, 2002). Ability of micronutrients absorption (especially zinc) is very important for optimum growth of plants. In most of the Iranian soils $\mathrm{pH}$ is high and they are also calcareous. In this type of soils solvability of micronutrients is less and it decrease absorption of micronutrients by plant, finally requirement of plants increasing to this elements (Mousavi et al. 2007). Maralin, (2009) showed that yield and $\mathrm{Zn}$ and Fe concentration of wheat increased by $\mathrm{Zn}$ and Fe foliar application. Plant height, stem diameter and leaf area index of maize where significantly increased by application of nitrogen and phosphorus fertilizer 8 weeks after sowing (Onasanya et al. 2009). Hamidi et al. (2008) in a study showed that fresh weight, number of leaves above the ear, yield of silage forage and vegetative growth of maize increased by application of PGPR (Plant growth promoting rhizobacteria). Hassanzadeh et al. (2006) reported grain yield and dry matter production in barley increased by application of 
phosphate-solution bacteria and chemical phosphorus fertilizer. El-Gizawy and Mehasen, (2009) showed that application of chemical phosphorus fertilizer with phosphate-solution bacteria had a significant effect on bean grain yield, yield components, nitrogen content, and content of phosphorus and zinc in the grain. Maize growth and dry weight increased by plant growth promoting rhizobacteria (PGPR) application (Zahir et al. 1998; Javed et al. 1998). Application of bio-fertilizer with $50 \%$ of chemical nitrogen, phosphorus and potassium (NPK) fertilizers increased maize vegetative growth, plant height, branch number, fresh and dry weight and total carbohydrate on dry matter as compared to chemical fertilizers treatments (Mahfouze and Sharafeldin, 2007). (Note 2)

With regards to importance of phosphate absorption from soil on the maize feeding the present research was done in order to evaluate the effect of bio-phosphate and chemical fertilizers combined with micronutrients foliar application on dry matter accumulation trend, growth and qualitative characteristics of maize (S.C.704). (Note 1)

\section{Materials and methods}

\subsection{Description of the project site}

This experiment was carried out during 2008-2009 at the Kerman Natural Resources and Agriculture Research Center, Iran, located in $56^{\circ} 34^{\prime}$ longitude and $29^{\circ} 55^{\prime}$ latitude and, $2044 \mathrm{~m}$ Altitude from sea level with an arid and semi-arid climate. The $\mathrm{pH}$ of soil field experiment was 8 and soil texture was loamy, (physical and chemical properties of soil in experimental field were presented in table 1). Experiment was conducted in split plot within a randomized complete block design with four replications. The main plots included foliar application of micronutrients containing $\mathrm{Fe}, \mathrm{Zn}, \mathrm{Mn}$, and $\mathrm{Cu}$ elements together with control application (non foliar application), and sub plot were considered four levels of phosphorus fertilizers: ( $\mathrm{T}_{1}: 0$ (no fertilizer), $\mathrm{T}_{2}: 100 \mathrm{~kg} \mathrm{ha}^{-1} \mathrm{P}_{2} \mathrm{O}_{5}, \mathrm{~T}_{3}$ : $100 \mathrm{~g}$ bio-phosphate, $\mathrm{T}_{4}: 100 \mathrm{~g}$ bio-phosphate with $50 \mathrm{~kg} \mathrm{ha}^{-1} \mathrm{P}_{2} \mathrm{O}_{5}$ ) Sowing was done as rows in $75 \mathrm{~cm}$ wide rows with $20 \mathrm{~cm}$ spacing within-rows with six rows per subplot by Single Cross 704 cultivar, (Single Cross 704 was chosen because this cultivar had superiority relative to other cultivar in the last few years in experimental region). Foliar application of micronutrients was done in 4 liters per thousand at stem extension and staminate inflorescence emergence stages. Prior to planting, seeds were inoculated with biological phosphorus fertilizer and chemical phosphorus fertilizer was utilized as strip takes under seed. All operations were done regularly during the growing season.

\subsection{Crop sampling and calculation}

Dry matter was determined 35 days after sowing of one square meter area in each plot after eliminating the marginal effect by oven at $70^{\circ} \mathrm{C}$ for 48 hours, and was repeated once every 15 days until the end of the growing period. 1000-seed weight and grain yield was measured at the end of growing season after of physiology maturity by harvesting $5 \mathrm{~m}^{2}$ from each plot. Percent of protein was obtained by following formula after determining amount of nitrogen in the laboratory by Kjeldahl method (Jones, 1991).

$\operatorname{Pr}=6.25 \times \mathrm{Nt} \times \mathrm{DM}$

$\operatorname{Pr}=$ Percent of protein

$\mathrm{Nt}=$ Percent of total $\mathrm{N}$

$\mathrm{DM}=$ Percent of dry matter

Concentration of zinc and phosphorus was obtained by atomic absorption and spectrophotometer methods respectively.

\subsection{Statistical analysis}

Data analysis was done by using SAS and MSTATC software. The ANOVA test was used to determine significant $(\mathrm{p} \leq 0.01$ or $\mathrm{p} \leq 0.05)$ treatment effect and Duncan Multiple Range Test to determine significant difference between individual means.

\section{Results and discussion}

\subsection{Dry matter accumulation}

Analysis of variance showed that dry matter accumulation was significantly affected by phosphorus fertilizer treatments during the stages of sampling (from 35 to 125 days after sowing); Also dry matter accumulation was significantly affected by foliar application of micronutrients during the stages of sampling except the first stage (35 days after sowing) (Table 6 and 2). Trend of dry matter accumulation showed that seed inoculation by biological phosphorus fertilizer before sowing increased dry matter accumulation. Highest dry matter accumulation $\left(1810 \mathrm{~g} / \mathrm{m}^{2}\right)$ was obtained by application of biological fertilizer $+50 \mathrm{~kg} \mathrm{ha}^{-1} \mathrm{P}_{2} \mathrm{O}_{5}$ (Figure. 
1). Maize resistant to lodging, precocity and its quality and quantity increased by increasing phosphorus availability; also grain yield increased by increasing weight and grain number per ear (Ehteshami et al. 2007). Bio-phosphate bacteria efficiency increased by application of biological phosphorus fertilizer combined with chemical phosphorus fertilizer. Pseudomonas bacteria in the bio-phosphate produced auxin and gibberellin hormones and vitamins, therefore dry matter increasing could be attributed to the ability of bacteria (Hassanzadeh et al. 2006). Effect of foliar application of micronutrients on dry matter accumulation appeared 50 days after sowing, the highest difference between foliar application of micronutrients and non foliar application treatments on dry matter accumulation was observed 95 days after sowing (Figure. 2).

\subsection{0-Seed weight}

1000-seed weight was significantly affected by biological and chemical phosphorus fertilizers, but foliar application of micronutrients had no significant effect on 1000-seed weight (Table 3). Application of biological fertilizer $+50 \mathrm{~kg} \mathrm{ha}^{-1} \mathrm{P}_{2} \mathrm{O}_{5}$ increased 1000 -seed weight to $304.97 \mathrm{~g}$ which was $9.77 \%$ higher as compared to control. Maize 1000-seed weight was dependent on the ability of plants to provide food for the reservoir and environmental conditions such as moisture and nutrients during grain filling (Andrade et al. 1999).

\subsection{Grain yield}

Analysis of variance showed that grain yield was affected by phosphorus fertilizers and foliar application of micronutrients (Table 3). According to the results, highest and lowest yields were obtained by application of biological fertilizer $+50 \mathrm{~kg} \mathrm{ha}^{-1} \mathrm{P}_{2} \mathrm{O}_{5}$ and control treatments respectively. Maize yield increased by application of biological phosphate fertilizer, that it could be due to increasing other nutrient absorption, also biological phosphate fertilizer can be used as a solution for increasing phosphate and micronutrients sorption in the alkaline soil (Hassanzadeh et al. 2006). Tahir et al. (2009) reported that grain weight and yield of maize increased by application of zinc. Increase of grain yield under the influence of phosphate fertilizers, biological fertilizer +50 $\mathrm{kg} \mathrm{ha}^{-1} \mathrm{P}_{2} \mathrm{O}_{5}$, can be attributed to the ability of phosphate solution bacteria in bio-fertilizer in increasing available phosphorus of insoluble phosphorus sources. In another study Rokhzadi et al. (2004) reported that grain yield of chickpea increased by application of biological fertilizers.

\subsection{Grain protein}

Percent of grain protein was significantly affected by biological and chemical phosphorus fertilizers, but foliar application of micronutrients had no significant effect on grain protein (Table 3). Mean comparisons showed that maximum $(9.74 \%)$ and minimum $(8.22 \%)$ grain protein was obtained by application of biological fertilizer +50 $\mathrm{kg} \mathrm{ha}^{-1} \mathrm{P}_{2} \mathrm{O}_{5}$ and control respectively (Table 4). Phosphate solubilizing microorganisms increased available phosphorus and nitrogen in the soil which increases their concentration by plant, also increased the grain protein (Mehrvarz et al. 2008). Hemati (2005) reported wheat protein increased by application of micronutrients such as $\mathrm{Zn}, \mathrm{Mn}$ and Fe.

\subsection{Grain phosphorus concentration}

Result showed that grain phosphorus concentration was significantly affected by biological and chemical phosphorus fertilizers and foliar application of micronutrients, also phosphorus fertilizers and foliar application interaction had a significant effect on percent of grain phosphorus (Table 3). Maximum phosphorous content $(0.24 \%)$ was obtained by application of biological fertilizer $+50 \mathrm{~kg} \mathrm{ha}^{-1} \mathrm{P}_{2} \mathrm{O}_{5}$ and foliar application of micronutrients which, was $25 \%$ higher as compared to control treatment (no fertilizer) (Table 5). Phosphorus uptake by plant decreased by increasing $\mathrm{Zn}$ in the soil, but $\mathrm{Zn}$ application by foliar application increased phosphorus absorption of soil by plants (Bukvic et al. 2003). Phosphate-solubilizing microorganisms had important role in phosphorus solubility and uptake. The bacteria released phosphorus from organic and inorganic soils during the mineralization process also increased the absorption of phosphate from phosphate rock, and save a reservoir of phosphorus in the presence of carbon unstable by mineralization process (Alikhan et al. 2009).

\subsection{Grain zinc concentration}

Phosphorous fertilizers and foliar application of micronutrients interaction had a significant effect on grain zinc concentration (Table 3). Mean comparisons showed that maximum zinc concentration $(16.15 \mathrm{mg} / \mathrm{kg}$ ) was obtained by application of biological fertilizer $+50 \mathrm{~kg} \mathrm{ha}^{-1} \mathrm{P}_{2} \mathrm{O}_{5}$ and foliar application of micronutrients; also minimum zinc concentration $(14.95 \mathrm{mg} / \mathrm{kg})$ was obtained by control. There wasn't significant difference between biological, chemical, biological fertilizer and $50 \mathrm{~kg} \mathrm{ha}^{-1} \mathrm{P}_{2} \mathrm{O}_{5}$, foliar and non foliar application on zinc concentration (Table 5). Foliar application is very fast method for providing requires elements in plants because nutrients are uptake quickly as compare to uptake that through plant roots. Zinc transferred to grain by remobilization and it remobilization was higher than other micronutrients (Ranjbar and Bahmaniar, 2007; 
Kochian, 1991). The concentration of zinc in wheat increased to three times by $\mathrm{Zn}$ and Fe foliar application in the tillering and heading stage (Maralian, 2009). Zinc absorption reduced by phosphorus application in the soil, but biological phosphorus fertilizers due to having phosphate solubilizing bacteria had no interfere on other elements uptake (Salimpour et al. 2010). Zakaria et al. (1997) reported phosphorus and zinc uptake by cotton increased by application of biological phosphorus fertilizers and zinc foliar application.

\section{Conclusion}

Application of phosphorus fertilizers combined with foliar application of micronutrients increased dry matter accumulation. Biological phosphorus fertilizers efficiency increases if combined with $50 \%$ chemical phosphorus fertilizers. Integrating biological and chemical phosphorus fertilizers with foliar application of micronutrients increased grain yield as compared to control. Biological phosphorus fertilizer with $50 \mathrm{~kg}$ chemical phosphorus fertilizer combined with foliar application of micronutrients increased grain zinc and phosphorous concentration. Zinc was available through foliar application for plant, thus application of phosphorus fertilizers had no negative effect on zinc uptake by plant in the soil, thereupon zinc and phosphorus concentration increased in the grain. Application of biological fertilizer was significantly increased 1000-seed weight and percent of grain protein, because nutrients absorption capability and plant absorption balance increased by phosphate-solubilizing microorganisms. Grain yield and quality increased by foliar application of micronutrients due to increasing elements transfer from leaves to grain. Application of chemical phosphorus fertilizer decreased to $50 \%$ by integrating biological and chemical phosphorus fertilizers without yield loss. Also environmental pollution was reduced by decreasing consumption of chemical fertilizers. Overall application of biological phosphorus fertilizers with chemical phosphate fertilizer in addition to yield increasing could be a strategy to achieve sustainable agriculture.

\section{References}

Ali, S, Riaz, A. K., Ghazal, M., Arif, M., Fida, M., \& Saiqa, B. (2008). Assessment of different crop nutrient management practices for yield improvement. Australian Journal of Crop Science, 2(3), 150-157.

Alikhan, A., Jilani, G., Saleem, A. M., Saqlan, N. S. M., \& Rasheed, M. (2009). Phosphorus solubilizing bacteria: Occurrence, mechanisms and their role in crop production. Journal of Agriculture Biology Science, 1, 48-58.

Andrade, F. H., Vaga, C., Ubart, S., Cirilo, A., Cantarero, M., \& Valentinuz, O. (1999). Kernel number

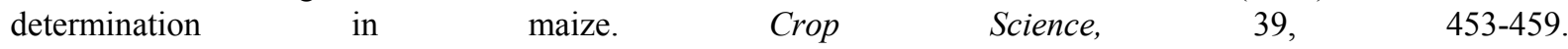
http://dx.doi.org/10.2135/cropsci1999.0011183X0039000200026x

Bukvic, G., Antunovic, M., Popovic, S., \& Rastija, M. (2003). Effect of P and Zn fertilization on biomass yield and its uptake by maize lines (Zea mays L.). Journal of Plant, Soil and Environmental, 49(11), 505-510.

Ehteshami, S. M. R., Aghaalikhani, M., Khavazi, K., \& Chaichi, M. R. (2007). Effect of phosphate solubilizing microorganisms on quantitative and qualitative characteristics of maize (Zea mays L.) under water deficit stress. Pakistan Journal of Biological Sciences 10(20), 3585-3591. http://dx.doi.org/10.3923/pjbs.2007.3585.3591

El-Gizawy, N. K. B., \& Mehasen, S. A. S. (2009). Response of faba bean to bio, mineral phosphorus fertilizers and foliar application with zinc. World Applied Sciences Journal, 6(10), 1359-1365.

Hamidi, A., Ghalavand, A., Dehghan-shoar, M., Malakuti, M. J., \& Asgharzadeh, A. (2008). The effects of application of plant growth promoting rhizobacteria (PGRP) on the Yield of fodder maize (Zea mays L.). Journal of Pajouhesh and Sazandegi, 70, 16-22.

Hassanzadeh, E., Mazaheri, D., Chaichi, M. R., \& Khavazi, K. (2006). Efficiency of phosphorus solubilizing bacteria and phosphorus chemical fertilizer on yield and yield components of barley cultivar. Journal of Pajouhesh and Sazandegi, 77, 111-118.

Hemati, A. (2005). Application of soil and spray application of iron, zinc and manganese on yield and bean protein plant. (The first National Conference beans Proceedings). Institute for Plant Science Ferdowsi University of Mashhad, Iran 2, 387-390.

Javed, M., Arshad, M., \& Ali, K. (1998). Evaluation of rhizobacteria for their growth promoting activity in maize. Pakistan Journal of Soil Science, 14, 36-42.

Jones, J. B. (1991). Kjeldahl method for nitrogen determination. Micro-Macro publishing Inc, Athens, GA, USA. pp 79.

Kannayan, S. (2002). Biofertilizers for sustainable crop production, Biothecnology of biofertilizers. Narosa Publishing House, New Delhi, India, 9-49. 
Kochian, L. V. (1991). Mecanismes of micronutrient uptake and translocation plant. Soil Science Society of America, 3, 229-296.

Mahfouze, S. A., \& Sharafeldin, M. A. (2007). Effect of mineral biofertilizer of growth yield and essential oil content of fennel. International Agrophysics, 21, 361-366.

Maralian, H. (2009). Effect of spray application of $\mathrm{Zn}$ and $\mathrm{Fe}$ on wheat yield and quality. African Journal of Biology, 8, 6795-6798.

Mehrvarz, S., Chaichi, M. R., \& Alikhani, H. A. (2008). Effect of phosphate solubilizing microorganisms and phosphorus chemical fertilizer on forage and grain quality of barely (Hordeum vulgare L.). American-Eurasian Journal of Agricultural and Environmental Sciences, 3(6), 855-860.

Mousavi, S. R, Galavi, M, \& Ahmadvand, G. (2007). Effect of Zinc and manganese foliar application on yield, quality and enrichment on potato. Asian Journal of Plant Sciences, 6(8), 1256-1260. http://dx.doi.org/10.3923/ajps.2007.1256.1260

Onasanya, R. O, Aiyelari, O. P., Onasanya, A., Oikeh, S., Nwilene, F. E., \& Oyelakin, O. O. (2009). Growth and yield response of maize (Zea mays L.) to different rates of nitrogen and phosphorus fertilizers in Southern nigeria. World Journal of Agriculture Science, 5, 400-407.

Ranjbar, G. A., \& Bahmaniar, M. A. (2007). Effect of soil and spray application of $\mathrm{Zn}$ fertilizer on yield and growth characteristic of bread wheat (Triticum aestivum L.) cultivars. Asian Journal of Plant Science, 6,1000-1005. http://dx.doi.org/10.3923/ajps.2007.1000.1005

Rokhzadi, A., Asgharzadeh, A., Darvish, F., Nour-Mohammadi, G., \& Majidi, E. (2004). Influence of plant growth promoting rhizobacteria on dry matter accumulation and yield of chickpea. American-Eurasian Journal of Agricultural \& Environmental Sciences, 3(2), 253-257.

Salimpour, S., Khavazi, K., Nadian, H., Besharati, H., \& Miransari, M. (2010). Enhancing phosphorous availability to canola (Brassica napus L.) using P solubilizing and sulfur oxidizing bacteria. Australian Journal of Crop Science, 4(5), 330-33.

Sharma, K., \& Namdeo, N. (1999). Effect of biofertilizers and phosphorus on growth and yield of soybean (Glycin max L. Merrill). Crop Research, 17, 160-163.

Tahir, M., Faiz, N., Nadeem, M. A., Khalid, F., \& Ali, M. (2009). Effect of different chelated zinc sources on the growth and yield of maize (Zea mays L.). Soil and Environmental Journal, 28(2), 179-183.

Zahir, A. Z., Arshad, M., \& Khalid, A. (1998). Improving maize yield by inoculation with plant growth promoting rhizobacteria. Pakistan Journal of Soil Science, 15, 7-11.

Zakaria, M. S., Mahmoud, H. M., \& Osama, A. M. (1997). Effect of phosphorus fertilization potion and spray application of cheated zinc and calcium on quantitative and qualitative properties of Egyptian, cotton (Jossypilum barbadense L.var.). Journal of Agriculture and Food Chemistry, 45, 3226-3330.

\section{Notes}

Note 1. Single Cross 704 (S.C.704)

Note 2. Nitrogen, phosphorus and potassium (NPK)

Table 1. Soil analysis result for physical and chemical characteristics

\begin{tabular}{|c|c|c|c|c|c|c|c|c|c|c|c|}
\hline Characteristic & $\begin{array}{c}\text { Soil } \\
\text { depth } \\
\end{array}$ & $\begin{array}{c}\text { Soil } \\
\text { texture }\end{array}$ & $\begin{array}{c}\text { OC } \\
(\%)\end{array}$ & $\begin{array}{c}\text { EC } \\
\left(\mathrm{dS} / \mathrm{m}^{-1}\right)\end{array}$ & $\mathrm{pH}$ & $\mathrm{P}$ & $\mathrm{K}$ & $\mathrm{Zn}$ & $\mathrm{Fe}$ & $\mathrm{Mn}$ & $\mathrm{Cu}$ \\
\hline Value & $0-30$ & loamy & 0.82 & 0.52 & 8 & 6.5 & 200 & 0.42 & 6.02 & 8.1 & 0.78 \\
\hline
\end{tabular}


Table 2. ANOVA of the effects of biological and chemical phosphorus fertilizers with foliar application of micronutrients on dry matter accumulation $\left(\mathrm{g} / \mathrm{m}^{2}\right)$

\begin{tabular}{|c|c|c|c|c|c|c|c|c|}
\hline & & & & & MS & & & \\
\hline SOV & $\mathrm{df}$ & $35^{1}$ & 50 & 65 & 80 & 95 & 110 & 125 \\
\hline Replication & 3 & 18.90 & 39.25 & 148.33 & 13545.44 & 2894.97 & 2937.11 & 2975.23 \\
\hline $\begin{array}{l}\text { Micronutrients } \\
\text { foliar } \\
\text { application }\end{array}$ & 1 & $1.00^{\mathrm{ns} 2}$ & $5021.02 * *$ & $4328.90^{* *}$ & $6308.20 * *$ & $140495.10^{* *}$ & $97887.60 * *$ & $49905.90 * *$ \\
\hline Error & 3 & 0.71 & 112.26 & 8119.81 & 1606.92 & 17427.54 & 9978.76 & 12050.45 \\
\hline $\begin{array}{l}\text { Phosphorous } \\
\text { fertilizers }\end{array}$ & 3 & $358.20 * *$ & $2900.50 * *$ & $55788.80 * *$ & $79283.80 * *$ & $147601.30^{* *}$ & $162077.40^{* *}$ & $137026.60 * *$ \\
\hline $\begin{array}{l}\text { Phosphorous } \\
\text { fertilizers } \times \\
\text { Micronutrients } \\
\text { foliar } \\
\text { application }\end{array}$ & 3 & $4.53^{\mathrm{ns}}$ & $327.45^{\mathrm{ns}}$ & $1135.28^{\mathrm{ns}}$ & $4757.80^{\mathrm{ns}}$ & $3747.63^{\mathrm{ns}}$ & $2283.25^{\mathrm{ns}}$ & $4361.60^{\mathrm{ns}}$ \\
\hline Error & 18 & 10.44 & 149.76 & 2256.94 & 5469.04 & 1946.44 & 9325.73 & 9718.57 \\
\hline CV (\%) & & 7.27 & 10.37 & 9.43 & 8.38 & 8.49 & 6.22 & 6.79 \\
\hline
\end{tabular}

1- Days after sowing

2- ns $=$ Non significant, $* *=\mathrm{p}<0.01$ and $*=\mathrm{p}<0.05$

Table 3. ANOVA of the effects of biological and chemical phosphorus fertilizers with foliar application of micronutrients on yield and quality characteristics of maize

\begin{tabular}{|c|c|c|c|c|c|c|}
\hline & & & MS & & & \\
\hline SOV & $\mathrm{df}$ & $\begin{array}{l}\text { Grain yield } \\
\text { (ton } / \mathrm{ha}^{-1} \text { ) }\end{array}$ & $\begin{array}{l}\text { 1000-seed weight } \\
(\mathrm{g})\end{array}$ & $\begin{array}{l}\text { Protein } \\
(\%)\end{array}$ & $\begin{array}{c}\mathrm{P} \\
(\%)\end{array}$ & $\begin{array}{c}\mathrm{Zn} \\
(\mathrm{mg} / \mathrm{kg})\end{array}$ \\
\hline Replication & 3 & 0.17 & 53.58 & 0.48 & 0.00005 & 0.14 \\
\hline Micronutrients foliar application & 1 & $2.39 * 1$ & $155.01^{\mathrm{ns}}$ & 0.23 & $0.0004 * *$ & $1.50 * *$ \\
\hline Error & 3 & 0.62 & 5.14 & 0.18 & 0.0000006 & 0.10 \\
\hline Phosphorous fertilizers & 3 & $13.67 * *$ & $1146.10^{* *}$ & $3.47 * *$ & $0.001 * *$ & $0.90 * *$ \\
\hline $\begin{array}{l}\text { Phosphorous fertilizers } \times \text { Micronutrients } \\
\text { foliar application } \\
\end{array}$ & 3 & $0.15^{\mathrm{ns}}$ & $15.75^{\mathrm{ns}}$ & $0.13^{\text {ns }}$ & $0.0001 *$ & $0.40^{*}$ \\
\hline Error & 18 & 0.35 & 35.63 & 0.16 & 0.00002 & 0.10 \\
\hline CV $(\%)$ & & 7.97 & 2.04 & 4.50 & 2.04 & 2.05 \\
\hline
\end{tabular}

1- ns $=$ Non significant, $* *=\mathrm{p}<0.01$ and $*=\mathrm{p}<0.05$ 
Table 4. Means comparison of effects of biological and chemical phosphorus fertilizers with foliar application of micronutrients on yield and quality characteristics of maize

\begin{tabular}{|c|c|c|c|c|c|c|}
\hline \multicolumn{2}{|c}{ Treat } & $\begin{array}{c}\text { Grain yield } \\
\text { (ton/ha) }\end{array}$ & $(\mathrm{g})$ & $\begin{array}{c}\text { Zn -seed weight } \\
\text { Protein } \\
(\%)\end{array}$ & $\begin{array}{c}\mathrm{P} \\
(\%)\end{array}$ & $\begin{array}{c}\text { Zn } \\
(\mathrm{mg} / \mathrm{kg})\end{array}$ \\
\hline \multirow{3}{*}{ Micronutrients } & Micronutrients foliar application & $7.79 \mathrm{a}$ & $294.52 \mathrm{a}$ & $9.06 \mathrm{a}$ & $0.24 \mathrm{~b}$ & $15.76 \mathrm{a}$ \\
\cline { 2 - 7 } & Non micronutrients foliar application & $7.23 \mathrm{a}$ & $290.12 \mathrm{a}$ & $8.89 \mathrm{~b}$ & $0.23 \mathrm{~b}$ & $15.33 \mathrm{~b}$ \\
\hline \multirow{3}{*}{ Fertilizer } & Chemical P & $8.09 \mathrm{~b}$ & $298.61 \mathrm{~b}$ & $9.24 \mathrm{~b}$ & $0.24 \mathrm{~b}$ & $15.64 \mathrm{a}$ \\
\cline { 2 - 7 } & Biological P $\times$ Chemical P & $8.81 \mathrm{a}$ & $304.97 \mathrm{a}$ & $9.74 \mathrm{a}$ & $0.25 \mathrm{a}$ & $15.86 \mathrm{a}$ \\
\cline { 2 - 7 } & Biological P & $7.32 \mathrm{c}$ & $287.90 \mathrm{c}$ & $8.69 \mathrm{c}$ & $0.24 \mathrm{~b}$ & $15.62 \mathrm{a}$ \\
\cline { 2 - 7 } & No fertilizer & $5.75 \mathrm{~d}$ & $277.81 \mathrm{~d}$ & $8.22 \mathrm{~d}$ & $0.22 \mathrm{c}$ & $15.07 \mathrm{~b}$ \\
\hline
\end{tabular}

1- Columns means followed by the same letter are not significantly different at 0.05 or 0.01 probability level

Table 5. Effects of biological and chemical phosphorus fertilizers and foliar application of micronutrients interaction on grain phosphorus and zinc concentration

\begin{tabular}{|c|c|c|c|}
\hline \multicolumn{2}{|c|}{ Treatments } & P (\%) & Zn (mg/kg) \\
\hline & Chemical P & $0.242 \mathrm{~b}^{1}$ & $15.99 \mathrm{ab}$ \\
\hline Micronutrients foliar application & Biological P $\times$ Chemical P & $0.257 \mathrm{a}$ & $16.15 \mathrm{a}$ \\
\hline & Biological P & $0.242 \mathrm{~b}$ & $15.97 \mathrm{ab}$ \\
\hline & No fertilizer & $0.220 \mathrm{~d}$ & $15.19 \mathrm{~cd}$ \\
\hline Non micronutrients foliar application & Chemical P & $0.234 \mathrm{c}$ & $15.29 \mathrm{~cd}$ \\
\hline & Biological P $\times$ Chemical P & $0.242 \mathrm{~b}$ & $15.57 \mathrm{bc}$ \\
\hline & No fertilizer & $0.232 \mathrm{c}$ & $15.27 \mathrm{~cd}$ \\
\hline & & 0.007 & $14.95 \mathrm{~d}$ \\
\hline
\end{tabular}

1- Columns means followed by the same letter are not significantly different at 0.05 or 0.01 probability level

Table 6. Means comparison of the effects of biological and chemical phosphorus fertilizers with foliar application of micronutrients on dry matter accumulation $\left(\mathrm{g} / \mathrm{m}^{2}\right)$

\begin{tabular}{|c|c|c|c|c|c|c|c|c|}
\hline \multicolumn{9}{|c|}{ Days after sowing } \\
\hline \multirow{3}{*}{ Micronutrients } & & 35 & 50 & 65 & 80 & 95 & 110 & 125 \\
\hline & Micronutrients foliar application & $44.57 \mathrm{a}^{1}$ & $130.52 \mathrm{a}$ & $540.10 \mathrm{a}$ & 928.73 & 1711.64 & $1607.32 \mathrm{a}$ & $1490.44 \mathrm{a}$ \\
\hline & Non micronutrients foliar application & $44.21 \mathrm{a}$ & $105.47 \mathrm{~b}$ & $466.54 \mathrm{~b}$ & 839.42 & 1579.121 & $1496.71 b$ & $1411.45 b$ \\
\hline \multirow{4}{*}{ Fertilizer } & Chemical P & $47.12 b$ & $117.74 \mathrm{~b}$ & $518.91 \mathrm{~b}$ & 899.97 & 1651.65 & $1582.93 b$ & $1433.34 b$ \\
\hline & Biological P $\times$ Chemical P & $51.43 \mathrm{a}$ & $142.87 \mathrm{a}$ & $611.38 \mathrm{a}$ & 988.45 & 1810.41 & $1721.75 \mathrm{a}$ & $1628.78 \mathrm{a}$ \\
\hline & Biological P & $43.35 \mathrm{c}$ & $114.80 \mathrm{~b}$ & $467.54 \mathrm{c}$ & 899.28 & 1641.621 & $1525.47 b$ & $1428.32 b$ \\
\hline & No fertilizer & $35.66 \mathrm{~d}$ & $96.85 \mathrm{c}$ & $415.46 \mathrm{~d}$ & 748.60 & 1477.86 & $1377.93 \mathrm{c}$ & $1313.33 \mathrm{c}$ \\
\hline
\end{tabular}

1- Columns means followed by the same letter are not significantly different at 0.05 or 0.01 probability level 


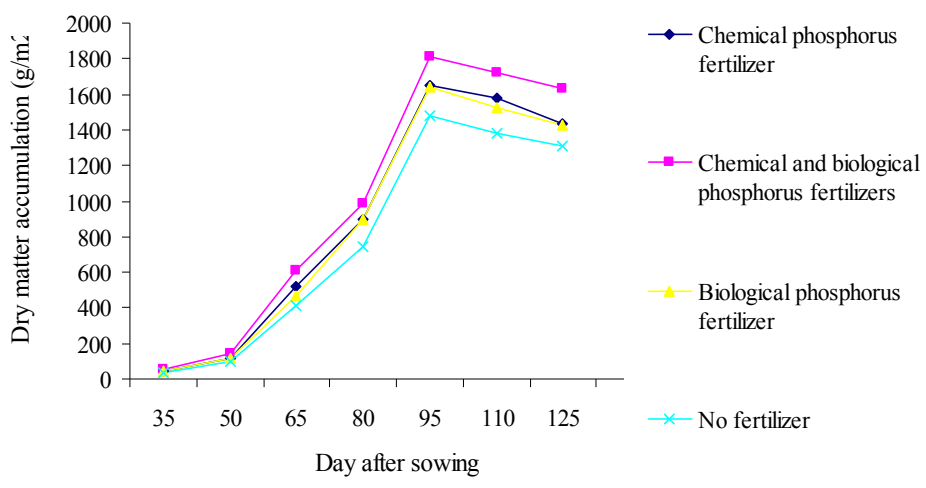

Figure 1. Effects of biological and chemical phosphorus fertilizers on dry matter accumulation $\left(\mathrm{g} / \mathrm{m}^{2}\right)$ (Error bars are the standard error of the mean)

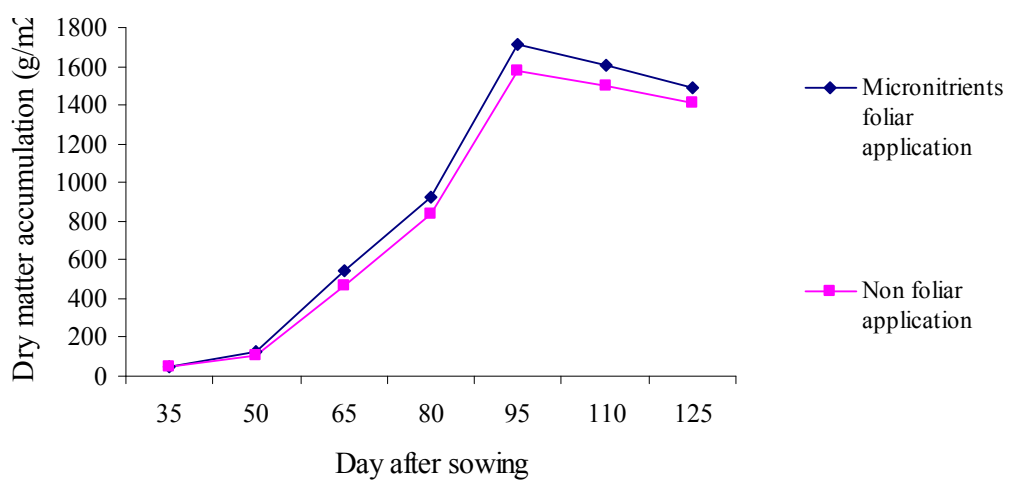

Figure 2. Effects of foliar application of micronutrients on dry matter accumulation $\left(\mathrm{g} / \mathrm{m}^{2}\right)$ (Error bars are the standard error of the mean) 